\title{
THE PREVAILING WINDS OF THE UNITED STATES
}

\section{Robert de C. Ward}

To cite this article: Robert de C. Ward (1916) THE PREVAILING WINDS OF THE UNITED STATES, Annals of the Association of American Geographers, 6:1, 99-119, DOI: 10.1080/00045601609357048

To link to this article: http://dx.doi.org/10.1080/00045601609357048

曲 Published online: 19 Feb 2009.

Submit your article to this journal

Џ Article views: 3

Q View related articles $\sqsubset$

Citing articles: 2 View citing articles 


\section{THE PREVAILING WINDS OF THE UNITED STATES ${ }^{1}$}

ROBERT DE C. WARD

$$
\text { CONTENTS }
$$

Inportance of Winds in Economic Climatology................. 99

General Relations of Pressures and Winds: Cyclonic and Topographic

Controls. . . ............................................ 100

January Winds ............................................. 102

July Winds $\ldots \ldots \ldots \ldots \ldots \ldots \ldots \ldots \ldots \ldots \ldots \ldots \ldots \ldots \ldots \ldots, 105$

Our American Monsoons............................... 111

Geographical Distribution of Wind Felocities in the United States..... 112

Maximum Wind Velocities.............................. 115

Seasonal and Diurnal Variation in Wind Velocity.................. 116

Bibliography. . . ...................................... 117

Importance of Winds in Economic Climatology.-To our prevailing winds we owe many of the larger characteristics of our climates. Winds import temperatures and moisture from a distance. If their way is not obstructed by mountain barriers, they tend to produce uniformity of climates over extended areas. They effectively wipe out many climatic boundaries. They bring marine conditions on shore. They carry land conditions off shore. They largely determine rainfall, and thus control the distribution of life. They bring us clean, pure air and are active agents in promoting health. Or, by carrying dust and micro-organisms, they may contribute to the prevalence of disease.

Wind velocity, too, apart from wind direction, has many human relations. The difference in our feeling of physical comfort or discomfort largely depends upon the amount of wind movement. The more extreme manifestations of wind force damage buildings and crops; wreck vessels; endanger or destroy human life. A knowledge of the highest velocities that are likely to occur is essential in the work of an engineer or of an architect, in the planning and the construction of buildings and of bridges.

As a source of power, winds are attracting more and more attention. We have in the United States scores of firms whose sole business it is to make windmills, hundreds of thousands of which are already in use. It is a significant illustration of the climatic control of the location of an industry that most of these windmill plants are situated in the open country of our middle west, where there is effective wind movement. American inventors have perfected powerful steel wind1 Presented (in abstract) before the Association of American Geographers, Washington, December, 1915. 
mills which are self-adjusting to varying wind directions and velocities; they make the maximum use of the minimum effective wind movement, and automatically turn out of the wind when the velocity becomes too great. In use over large sections of the United States where the wind velocities have proved themselves to be most usable and reliable, our windmills are to-day pumping water for irrigation, for cattle, and for domestic uses; they are grinding corn, cutting wood, and churning. The time is probably not far distant when these windmills will be used to generate electrical energy, which, when stored and accumulated, will supply us locally at a minimum expense with heat, light and power. In times of slack wind, combustion engines, started automatically, or storage batteries, may be used to keep up the supply of electricity. Our wind velocities have proved themselves a climatic asset of whose value we have, for the most part, been strangely unconscious. They have a very real human significance.

Generat Relations of Pressures and Winds: Crclonic and Topograpiric Controus.- The continental area of the United States lies almost entirely within what is generally known as a belt of "prevailing westerly winds." These are members of the general atmospheric circulation. They would, however, blow from a general westerly direction much more distinctly if there were no North American continent with its seasonal changes of temperature and of pressure; with its mountains and its lowlands; with its Great Lakes and its storms, to interfere with them. The local influences of the changing seasonal pressures over the continent and over the adjacent oceans are, to a large extent, paramount to the general control over air movement exercised by the differences of pressure between the equator and the higher latitudes. To the south, the states bordering on the Gulf of Mexico, subtropical already in latitude, share also in the wind system which is characteristic of tropical countries, i. e., the trades. These trade winds, like the prevailing westerlies, find their initial cause in the great permanent differences of temperature and of pressure between equator and poles, but over the southern United States, as in other regions also, are greatly modified by the local pressure distribution.

Year after year the orderly succession of the seasons brings a warming and cooling of our continent. The pressures change systematically, not only over the continent itself, but also over the adjacent oceans. And, sympathetically also, our prevailing winds show a seasonal change in their directions. But other influences play their part. Our great mountain systems are barriers in the path of the winds. Mountains turn winds aside, as in the case of the prevailing westerlies off our southern Pacific coast in winter, noted by Ferrel ${ }^{1)}$; or cause them. 
to flow around the obstruction, as in the case of northwest and southeast winds in the Appalachians ${ }^{2)}$; or otherwise serve as divides between winds of different directions and characteristics. The general configuration of the country; the trend of mountains and of valleys; locations to windward or to leeward of mountains or of lakes; the hour of the day or night; exposure to land and sea breezes: all these factors have a part in controlling our winds, both in direction and in velocity. Then, varying from day to day, more temporary than any of these other controls, comes the ever-changing influence of our cyclones and anticyclones. The dominance of these passing conditions over our air movements is often so complete that easterly winds are of frequent occurrence thruout the belt of our prevailing westerlies. Many persons, indeed, especially along or near our northern Atlantic coast, find it difficult to believe that our prevailing winds are really from the west $^{3)}$. Easterly storms; easterly winds blowing on shore from a high-pressure area off the coast; even the local and relatively insignificant sea breeze, all combine to keep up this impression. Frequent as are the interruptions of our prevailing westerly winds near the surface, the upper currents follow their regular course from the west with remarkable persistence. The clouds which they carry tell us this story. And so do the observations from Mt. Washington, Pike's Peak, and other elevated stations. The relation between our temporary cyclonic and our prevailing westerly winds was clearly recognized by Blodget ${ }^{4}$, who also saw the evidence of prevailing winds from west to east in the trend of the isotherms and in the difference in temperature and humidity on the Pacific and Atlantic sides of the continent.

The wind direction and velocity at any station, as shown on our daily weather maps, depend upon the controls just referred to, together with others, such as the local exposure of the wind instruments, e. g., their height above the ground, the influence of adjacent buildings, etc. Many of our stations show quite persistent influences of local topography upon their wind directions, resulting from the position of a neighboring mountain; the trend of a valley, or from exposure to local mountain and valley winds ${ }^{5}$. The winds at our northern stations, for example, are more affected by storm controls than those farther away from the main storm paths. The wind directions shown on our weather maps are, therefore, the complex resultant of many variables. The wind arrows on these maps, as well as on the usual charts which show the monthly or annual prevailing wind direction at each Weather Bureau station, emphasize the local peculiarities of each place. They do not give us the broadly generalized view of our winds which we often need in a study of our larger climatic conditions and of their controls. What we here want to know is the general 
sweep of our winds, i. e., our wind systems, over the different sections of the United States. In Figs. 1 and 2 the prevailing winds for January and July are thus broadly generalized. No attempt is made to show details, or to ensure absolute accuracy of direction over every portion of every State. The purpose is only to give a general view of the larger wind movements. The effects of local topography have, so far as is reasonably possible, been disregarded, and in cases where several wind directions have almost equal percentages of frequency, the prevailing direction has been taken to be that which agrees with the general conditions of wind movement over neighboring districts. Useful as such generalized wind charts are in a climatological study, it must constantly be borne in mind that the interference with these prevailing wind directions, under temporary cyclonic and anticyclonic control, is both important and frequent, especially in winter, and over the northern tier of states.

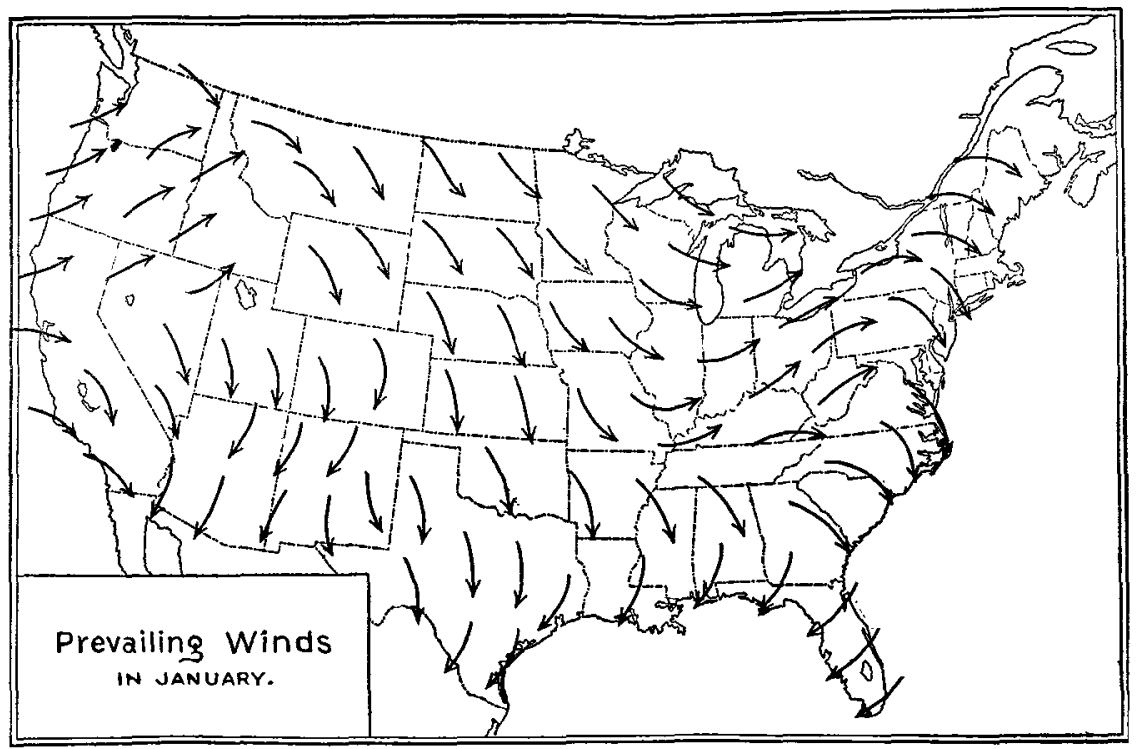

Figure 1

JANUARY Winds.-Our winter winds are markedly under the control of a seasonal pressure distribution peculiar to North America. This is less fixed, less clearly defined, more complex than that of Eurasia. Hence our winter wind systems are also less emphatic. We have no great dominating winter anticyclone. Generalizing broadly, and summarizing very briefly, the tropical high-pressure belt over the adjacent oceans expands over the North American continent into a ridge of high pressure (30.20 ins.), lying between the well-marked low-pressure areas of the northern North Atlantic and 
northern North Pacific ${ }^{6}$. In response to this mid-winter pressure distribution certain large and fairly easily recognizable wind systems are developed. Taken as a whole, the centrifugal tendency, characteristic of continents during their winter season, is at once apparent.

In the eastern United States ("Eastern Province") northwesterly offshore winds generally prevail along our northern and middle Atlantic seaboard, under the combined control of the low-pressure system which overspreads the northern part of the Atlantic Ocean, extending as an elongated trough from northeastern North America (Davis Strait and Baffin Bay) to northwestern Europe. ${ }^{2}$ These northwesterly winds increase in velocity and in frequency as we go farther north into $\mathrm{New}$ England, and still more so outside of our own territory in northeastern Canada, where the North Atlantic low-pressure system exerts a more marked control. They become less marked towards the south, where there is an increasing tendency towards westerly and southwesterly and, especially on the coast of the southern Atlantic States, even toward northeasterly and northerly directions. We owe the severe winters of our middle and north Atlantic coast states to these offshore winds. They come from the cold northern interior. They cause discomfort and often much suffering among those who are unable to secure proper protection in the way of clothing, heat, and adequate food. But to these same cold winds we owe the ice supply from our northern lakes and ponds and rivers, so indispensable during our hot summers. They also very greatly increase our need of fuel for heating purposes, and thus enormously stimulate our coal industry, with its resulting demand for labor and for railroad and steamship transportation.

The influence of the Atlantic Ocean is felt when our winds blow onshore under the control of some passing high or low-pressure system. These easterly winds temporarily interrupt the prevailing offshore movement of the air. They bring us our chilling northeast snowstorms, and our warmer, often rainy, southeasterly and southerly storm winds. Such interruptions of the offshore tendencr are frequent in the eastern United States, where our storm control is marked. Our winter winds and weather are hence very changeable. In eastern Asia, on the other hand, where the general seasonal pressure control over the winds is more emphatic, and where the storm control is relatively less important, the northwesterly winds remain in much less disturbed possession. There the latter are indeed so marked that they deserve the name of winter monsoons. Eastern Asia, for this reason, has drier and less cloudy winters than those which characterize our Atlantic seaboard.

A comparison with Europe also naturally suggests itself. While our

2 The climatic provinces which are used as the basis of the discussion in the present paper are those suggested by the author in his "Climatic Subdivisions of the United States," Bull. Amer. Geogr. Soc., Vol. XLVII, Sept., 1915, pp. 672-680. 
own Atlantic coast is having its severe winters, western, and especially northwestern, Europe are kept abnormally mild and temperate because their prevailing southwesterly winds are blowing from the warm Atlantic Ocean and from more southern latitudes. Thus the eastern and western sides of the North Atlantic inevitably differ greatly in climate. Similar temperatures are met with, not in the same, but in widely separated latitudes. As seen on the chart of mean annual temperatures, one may go north in western Europe a thousand miles without finding as great a decrease in temperature as that met with in half that distance on the eastern coast of North America. Northwestern Europe is to be compared with our northern Pacific coast, and with British Columbia, not with our Atlantic coast. Europe is singularly favored in its exposure to these warm winter winds.

For the sake of clearness and of simplicity in dealing with the prevailing winds, we may divide the interior of the United States (" Eastern Province") east of the Great Plains and north of the "Gulf Province," into "Ohio Valley and Lower Lakes" and "Mississippi Valley west." Prevailing southwesterly and westerly winds characterize the former of these two divisions; northwesterly and northerly winds prevail over the latter. The northern portion of the Upper Lakes shares in the wind system of the latter district". In the States bordering on the Gulf of Mexico ("Gulf Province"), Florida has prevailingly northeast winds (Trades); while northerly directions predominate along the northern and western shores of the Gulf. There is also a considerable southerly (S. E.) component in the western Gulf coast section, although this is not shown on the map (Fig. 1). All across the broad expanse of our Great Plains ("Plains Province"), and even into the western plains of Canada, the great northerly and northwesterly sweep of winds, noted as characteristic of the States just west of the Mississippi River, continues as a dominant climatic feature. Over the northernmost section, and across the Canadian border, a tendency towards gentler wind movement, with many calms, is observable.

It is difficult to generalize the winds in the region between the Rocky Mountains and the Sierra Nevada-Cascade system ("Plateau Province"). Here the enclosing mountain barriers and the broken topography greatly interfere with a free sweep of the winds. Over the southern portion of the district ("Southern Plateau"), blowing out from the continent, northerly wind directions are frequent, while, under the control of the general pressure distribution, southwesterly winds are most common farther north ("Northern Plateau"). Shut off by the high barrier of its eastern mountains, the Pacific slope ("Pacific Province") has its own wind system, prevailingly from the southwest and west along shore. These winds are chiefly under the 
control of the marked low-pressure area of the North Pacific, but the tropical high-pressure belt, lying farther south, also influences the wind directions, especially along the southern portion of the coast. In the interior, notably in California, wind directions are greatly modified by topography. It is to its prevailing westerly winds, coming directly from a conservative ocean, that our Pacific slope owes the far-famed mildness and equability of its winters. Warm winds blow there most of the time in the cold season, while on the Atlantic seaboard, it will be recalled, the prevailing winter winds (northwest) are the coldest that can blow. Hence the latter province has notably severe winters, especially in northern sections. The passage of winter storms, chiefly over the northern Pacific coast, or the presence of a highpressure area to the east or northeast, brings temporary easterly winds in Washington, Oregon and California. On the Pacific slope, northeast winds in winter come from a cold land, and bring low temperatures. On the Atlantic coast they are damp, and usually bring rain or snow.

The following table gives a compact summary of the generalized prevailing winds of the United States in winter (January). All details are disregarded. Only the broadest features of the wind systems are indicated.

COMPACT SUMMARY OF THE PREVAILING WINDS OF WINTER

Eastern Province:

a. Atlantic Coast: N.W., W.

b. Ohio Valley and Lower Lakes: S.W., W.

c. Mississippi Valley west: N.W., N.

Gulf Province:

a. Eastern (Florida): N.E.

b. Central: N., N.E.

c. Western (Texas) : N., N.E., S.E.

Plains Province: N.W., N.

Plateau Province:

a. Northern: S.W.

b. Southern: N., N.W.

Pacific Province:

a. Northern: S.W., W.

b. Southern: W., N.W.

JULY WINDs.-Our wind maps are misleading if we think of them as representing anything fixed or settled. They are really only " snapshots" of conditions which are in a more or less constant state of 
transition. Our prevailing winds are great sweeping currents, under the control of seasonally changing pressure distribution. The winds for January and July are chosen for discussion because these are our midwinter and midsummer months, and their winds are fairly characteristic of these two seasons. But all the year through a gradual shift is taking place, from the conditions of one month to those of the next. January and July are only temporary stages on the way. We wholly fail to appreciate what these seasonal and monthly changes mean unless we can imagine our winds in this constant state of transition.

Continental and marine pressure conditions different from those of winter have a marked effect in controlling the general flow of our summer winds. A low-pressure trough (29.75 inches at the centre) extends across western North America, roughly from north to south, merging on the south with an east-and-west belt of low pressure over Central and northern South America. The North Atlantic high-

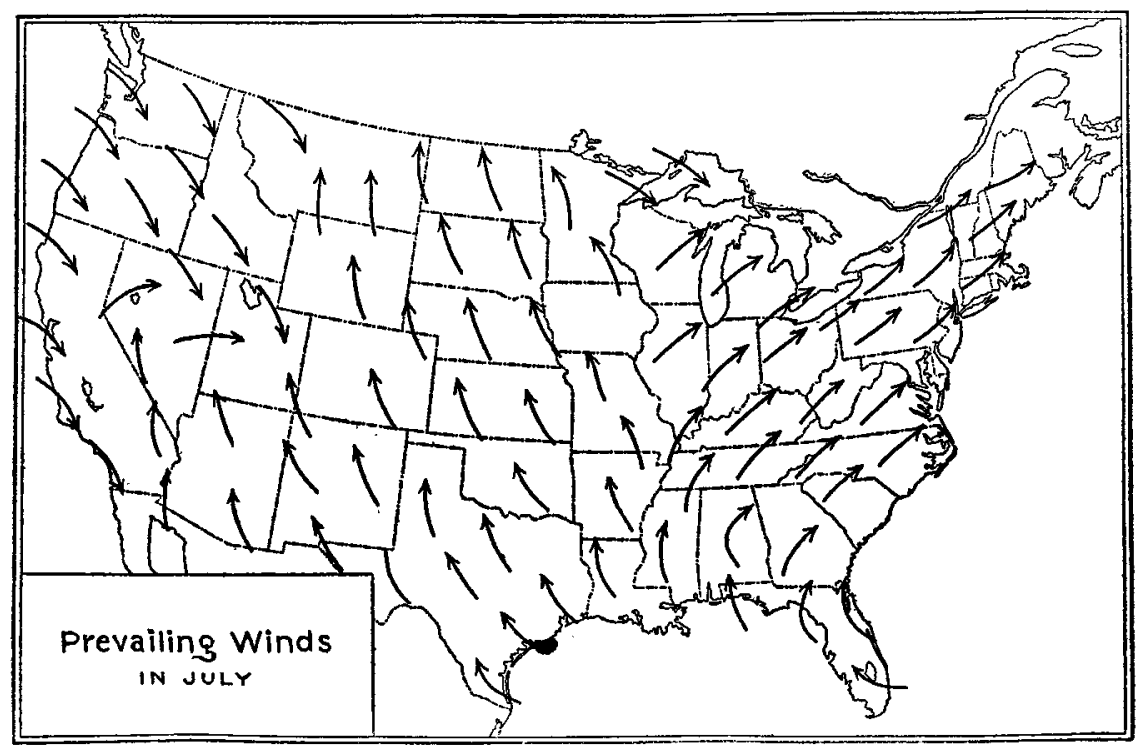

FIGURE 2

pressure belt overlaps the continent in the southeast, and the Pacific high-pressure area, with crowded isobars on its eastern side, encroaches on the land along our Pacific coast. The two ocean high-pressure systems, which form part of the so-called tropical high-pressure belt, are thus separated by the continental trough of low pressure. From the cooler oceans onto the warmer land the winds tend to blow centripetally, guided by these seasonal pressures, the unchanging topography, and the temporary storm control. From midwinter to midsummer, 
taking place gradually, as winter merges into spring and spring later merges into summer, there is a great swing of the winds over the eastern United States, from the prevailing northerly and northwesterly directions of January to a prevailing southwesterly and southerly direction in July. Southerly winds gradually advance northward and eastward from the Gulf of Mexico as spring comes on, until, by early summer, they prevail (as southerly or southwesterly winds) over practically the whole of the United States east of the Rocky Mountains. In July, the Atlantic coast and most of the Ohio Valley and Lower Lakes district have prevailing southwesterly winds, under the combined control of the North Atlantic high and low-pressure systems. This seasonal change in direction is most marked along the Atlantic slope. In the Ohio Valley and Lower Lake district, the prevailing wind directions are essentially the same in summer and in winter, the general pressure gradient being in about the same direction thruout the rear. Supan has shown the seasonal wind changes along our Atlantic coast by means of the following table ${ }^{8)}$. The minus (-) sign indicates a decrease in that particular wind direction from winter to summer. In the northern section, the change is mostly between northwesterly and southwesterly; in the southern, mostly between north and south. Hence it is more marked, i. e., it covers a larger number of degrees, in the south.

CHANGES IN WIND FREQUENCX $(\%)$ FROM WINTER TO SUMMER (SUPAN).

$\begin{array}{crrrrrrrr}\text { District } & \text { N } & \text { NE } & \text { E } & \text { SE } & \text { S } & \text { SW } & \text { W } & \text { NW } \\ \text { Northeastern Coast ......... } & -\mathbf{5} & -2 & 1 & 4 & 7 & 14 & -3 & -16 \\ \text { Middle Atlantic Coast....... } & -2 & -3 & 0 & 6 & 8 & 7 & -2 & -14 \\ \text { South Atlantic Coast......... } & -7 & -4 & 3 & 8 & 7 & 4 & -1 & -9 \\ \text { Northern Gulf Coast......... } & -10 & -6 & 0 & 3 & 5 & 9 & 3 & -\mathbf{5}\end{array}$

Von Hann has summarized the winter and summer wind directions (in percentages) on the eastern coast of North America, in middle latitudes, as follows ${ }^{\text {9) }}$ :

FREQUENCY OF WIND DIRECTIONS (\%) IN MIDDLE LATITUDES ON THE EASTERN COAST OF NORTH AMERICA (VON HANN).

$\begin{array}{lrrrrrrrrr} & \text { N } & \text { NE } & \text { E } & \text { SE } & \text { S } & \text { SW } & \text { W } & \text { NW } & \text { Resultant } \\ \text { Winter } \ldots \ldots \ldots . . . & 11 & 15 & 6 & 6 & 7 & 18 & \mathbf{1 4} & 23 & \text { N } 58^{\circ} \mathrm{W} \\ \text { Summer ......... } & 8 & 12 & 6 & 11 & 13 & 28 & 9 & 13 & \text { S } 45^{\circ} \mathrm{W} \\ \text { Difference } \ldots \ldots \ldots & 3 & 3 & 0 & -5 & -6 & -10 & 5 & 10 & \end{array}$

The dominance of the winter northwest winds, and of the summer southwest winds, is clearly seen here. With the seasonal change from summer to autumn, and then to winter, the northwesterly winds advance from the continental interior toward the south and east until 
they, in their turn, dominate the region of the Plains, the Mississippi Valley west, and much of the Atlantic Coast.

The Gulf States ("Gulf Province") are crossed by what may perhaps be called a branch of the northeast trades which, under the control of the Atlantic high-pressure area and of the lower pressure over the continent, become southerly or southeasterly winds. The States lying immediately west of the Mississippi Valley, and the Great Plains ("Plains Province"), are crossed by a great sweep of southerly and southeasterly winds, which extend north even across the Canadian line. Professor A. J. Henry has pointed out that, in late spring, the southerly winds of the Mississippi Valley apparently divide over the Great Lakes into two branches, one forming part of the summer southerly and southeasterly winds of the Missouri Valley and the Plains, and the other forming part of the southwesterly winds of the Ohio Valley system ${ }^{10)}$.

This great body of moist southerly air, after crossing a wide expanse of warm Gulf and Atlantic waters, blows inland over the eastern United States around the western margin of the North Atlantic highpressure area. To it we owe most of our beneficent warm season rains and thundershowers. Without these our important staple crops east of the Rocky Mountains would never reach maturity. To these same winds, coming from warm southern latitudes, our hot eastern summers are chiefly due. Thus the prevailing summer winds along our Atlantic seaboard (S.W.) are our warmest winds. Except when temporarily interrupted by easterly winds from the ocean (see p. 103), or by northwesterly winds from higher and cooler latitudes, they assure us a preponderance of high temperatures. The tempering influence of the Atlantic has little opportunity to make itself felt. Our warm southerly summer winds bring us our sunstroke weather; our epidemics of cholera infantum; our spells of suffering in our crowded cities. The development of summer resorts in the north, among the mountains, and on the seacoast, is in no small degree due to these same warm winds. Sea bathing and electric fans, thin clothing and cooling beverages, find much of the explanation of their use and enjoyment in the fact that the dominant winds of our eastern summers are the warmest winds that we can have. In recent years, economic consequences of no small importance have been attributable to these same southerly winds. In New England, the brown-tail moth, a pest which had already done great damage to fruit and other trees in Massachusetts, was spread northward and eastward over the adjoining States by the southwesterly winds. And in Texas, the cotton boll weevil, another pest of serious economic importance, was also spread northward by the prevailing southerly winds of that region.

A comparison with Europe is interesting. Western and northwest- 
ern Europe have their prevailing summer winds from a cool ocean and a higher latitude: On our Atlantic coast the prevailing summer winds are from a warm land and a lower latitude. Hence, in Europe, the tempering influence of the conservative Atlantic largely counteracts the warming influence of the land, while along the eastern seaboard of the United States the land influence predominates. Our severe eastern climates, with their cold winters and hot summers, largely find their explanation in the directions of our prevailing winds.

Over the "Plateau Province" the winds of summer show a tendency toward northerly and northwesterly directions in the north, while in the south, southerly directions prevail. As in winter, however, the enclosing mountain barriers of this region, and the local topography, greatly interfere with the development of broad, sweeping wind systems. Local mountain and valley winds, their direction determined by the immediate topography, are characteristic phenomena. They often exercise an important control over the conditions of frost occurrence.

Supan has summarized the changes in wind direction from winter to summer for certain districts west of the Mississippi River in the following table ${ }^{8}$. The minus (-) sign indicates a decrease in that particular wind direction from winter to summer.

CHANGES IN WIND FREQUENCY (\%) FROM WiNTER TO SUMMER (SUPAN).

$\begin{array}{rrrrrrrrr}\text { District } & \text { N } & \text { NE } & \text { E } & \text { SE } & \text { S } & \text { SW } & \text { W } & \text { NW } \\ \text { Upper Mississippi Valley..... } & -2 & 1 & 2 & 3 & 4 & 3 & -3 & -8 \\ \text { Upper Missouri Valley...... } & -11 & 2 & 7 & 9 & 11 & 1 & -8 & -10 \\ \text { Arkansas and Red Rivers and } & & & & & & & & \\ \text { Texas .................. } & -15 & -4 & 5 & 21 & 11 & -1 & -5 & -12 \\ \text { Lower Colorado River......... } & -28 & -6 & 2 & 14 & 26 & 6 & -2 & -11\end{array}$

The decrease in the northerly and the increase in the southerly directions from winter to summer is striking, especially in the case of the last-named district, where the change is almost monsoonal in character. The annual reversal of the wind system at Yuma, Ariz., is shown in the following table ${ }^{11}$.

RELATIVE FREQUENCY OF THE WINDS (EXPRESSEd IN PERCENTAGES) AT YUMA, ARIz., AS DEDUCED FROM TRI-DAILY OBSERVATIONS, 1876-1888.

\begin{tabular}{|c|c|c|c|}
\hline January...$\ldots \ldots \ldots$ & N 28 & NE 19 & $\begin{array}{ll}\text { NW } & 14 \\
\text { SW } & 19\end{array}$ \\
\hline July . . . . . . . . . . . . & S 23 & SE 21 & SW 19 \\
\hline
\end{tabular}

On the Pacific Slope ("Pacific Province") the summer winds are westerly, as in winter, but the northerly component is more marked in the warm season, the southerly in the cold. The prevailing northwesterly winds of summer are so regular, especially toward the north (e. g., Oregon), that they are often locally known as trade winds. 
The change from winter to summer is due to the combined influence of the warm continent and of the more northerly summer position of the Pacific high-pressure system. From winter to summer there is a loss in northeast, east and southeast winds, and a gain in west and northwest winds. This is in part attributable to the frequent cyclonic and anticyclonic winds from easterly points during the winter season. The coast mountains tend to deflect the winds along the shore. Thru the Golden Gate, at San Francisco, the winds blow into the hot Valley of California, and are there turned north and south. The southerly winds of summer are a marked climatic feature of the Sacramento Valley. They serve somewhat to moderate the heat of that wellenclosed and easily warmed district. And they are so steady that boatmen on the Sacramento River can count on them for sailing upstream.

The prevailing summer, winds along the Pacific coast are dry, because, blowing out on the eastern side of the North Pacific anticyclone, they have had no opportunity to take up much moisture, and furthermore they are advancing into lower latitudes and therefore warming. The contrast between the prevailing damp and warm summer winds on the western side of the North Atlantic high-pressure system, and the drier and cooler winds on the eastern side of the North Pacific high-pressure system is striking, and climatically very significant. It is also significant that the prevailing summer winds on our Pacific coast come from a cool ocean and higher latitudes, just as is the case, already noted, in northwestern Europe. In the United States, however, our western mountains practically limit the moderating influence of the westerly winds to a comparatively narrow belt between the Sierra Nevada-Cascade barrier and the Pacific Ocean, and the transition from the more moderate conditions of the immediate sea coast to the more extreme climates of the interior is rapid and sharp. In Europe, on the other hand, there is a very gradual transition from the marine climates of the outermost western coastal strip to the more severe continental conditions of Russia. Again, in Europe there are very uniform climatic conditions over all the Mediterranean region, from Portugal and southern Spain across Italy and Greece, and even into Asia Minor. Civilization in the Old World was therefore able to spread westward from the Orient over a large area of remarkable climatic uniformity. In North America a similar "Mediterranean climate" is found only over a relatively narrow zone, essentially in central and southern California. The smaller area of the subtropical belt of Mediterranean climates in North America than in Europe was clearly explained by Blodget"12). "If the Gulf of Mexico were similar in position to the Gulf of California, yet extended inland like the Mediterranean, the districts of the various local pecu- 
liarities now bordering on the Mediterranean would be reproduced. - . The space where we may look for phenomena correspondent to those of the Mediterranean is here relatively small."

The prevailing winds of summer, broadly generalized, may be briefly summarized as follows:

COMPACT SUMMARY OF THE PREVAILING WINDS OF SUMMER Eastern Province:

a. Atlantic Coast: S.W., W.

b. Ohio Valley and Lower Lakes: S.W.

c. Mississippi Valley west: S.E., S.

Gulf Province: S., S.E.

Plains Province: S., S.E.

Plateau Province:

a. Northern: N.W.

b. Southern: S.

Pacific Province: N.W., W.

Our American Monsoons.-Monsoons in the Indian sense, of great seasonally inflowing and outflowing winds, strongly contrasted in direction and in characteristics, and markedly controlling the life and activities of all the people, we cannot claim. Yet that a distinct monsoonal tendency exists over a large section of our country was clearly noted at least as far back as the time of Blodget, who wrote of the winds of Texas, as "something very near a monsoon ${ }^{13)}$." Later (1875) Coffin discussed, in a general way, the monsoonal tendencies in our winds ${ }^{14)}$. And Ferrel, fifteen years later, considered the conditions which give rise to monsoons and referred to the monsoon influence on the winds of the southern United States and of the Gulf of Mexico ${ }^{15)}$. The general swing from northerly winds in winter to southerly winds in summer over the Great Plains and eastward to the Mississippi River (see p. 107), is especially well marked in the south (e. g., Texas). Here, as pointed out by von Hann, the seasonal variation of relative humidity is most analogous to that of southern and eastern Asia. The weaker general pressure controls, and the frequent cyclonic interruptions of these seasonal winds in the United States, prevent any such marked development as that attained by the monsoons of India. Our Texas monsoons have been studied by Professor M. W. Harrington, who also used the name monsoons for the seasonally changing winds on the Pacific coast south of San Fran- 
cisco $^{18)}$. The northerly (winter) monsoons first appear distinctly in December. While having generally a higher velocity than those of the summer, they do not maintain themselves under unfavorable conditions. They are not infrequently strengthened, under temporary conditions of rapid pressure change, into a northerly gale of high velocity, known as the "norther." This wind is one of the marked characteristics of Texas climate, even far out onto the western Texas plains. At times, "northers" reach as far south as Guatemala and Honduras; cross Tehuantepec, and are reported by ships in that portion of the Pacific Ocean. In midsummer a territory about 500 miles wide and about 1,000 miles long, reaching as far as the Canadian boundary, is under the general control of the southerly (summer) monsoons. These are weaker than those of winter, and bring clear weather, unless a low-pressure area is approaching. East of the Mississippi and south of the Ohio there is no good evidence of them except on the Gulf coast, as far as Mobile. These southerly or southeasterly winds are welcome cooling agencies during the heat of the Texas summer, even at considerable distances from the coast of the Gulf of Mexico.

Geographical Distribution of Wind Velocities in the United States.-Accurate charts of our average wind velocities are difficult to draw. There have been many changes in the locations and in the exposure of our anemometers. Especially has this been true in our large cities, where the increasing heights of our sky-scrapers have made the placing of these instruments on the lower buildings less and less desirable. As the anemometers have been exposed on the tops of higher and higher buildings, the recorded wind velocities have become greater and greater. Fig. 3 shows the average hourly velocity of our winds as determined by Mr. P. C. Day, of the United States Weather Bureau $^{17)}$. The figures indicate the hourly wind velocity estimated for the uniform elevation of 100 feet. A "correction" has been applied to allow for the retardation of the winds by the buildings of our large cities.

In the eastern United States ("Eastern Province") stations close along the Atlantic coast and on the Great Lakes have the most wind. The line of ten miles an hour closely parallels the margins of these bodies of water. Somewhat higher winds (10-14 miles an hour) prevail at the most exposed points on the Atlantic seaboard, e. g., at Cape Cod, Mass., and Cape Hatteras, N. C., and also to the leeward of Lakes Erie and Ontario. In the "Gulf Province," many coast stations have about the same wind movement as that of the Atlantic and Great Lakes stations. The small amount of friction over water, and exposure to frequent storm winds, account for these high velocities. Lashed by 
winter gales and autumn hurricanes, the waters off Cape Hatteras are proverbially rough. It is but natural that such meteorological handicaps to navigation should have led to the digging of the Cape Cod Ship Canal, completed in 1914, and to the project of constructing a protected waterway for vessels among the islands and across the lagoons and bays along the Atlantic coast farther south. The popular designation of a windy city, often confined to Chicago, applies with equal truth to other stations on the Great Lakes and the Atlantic coast.

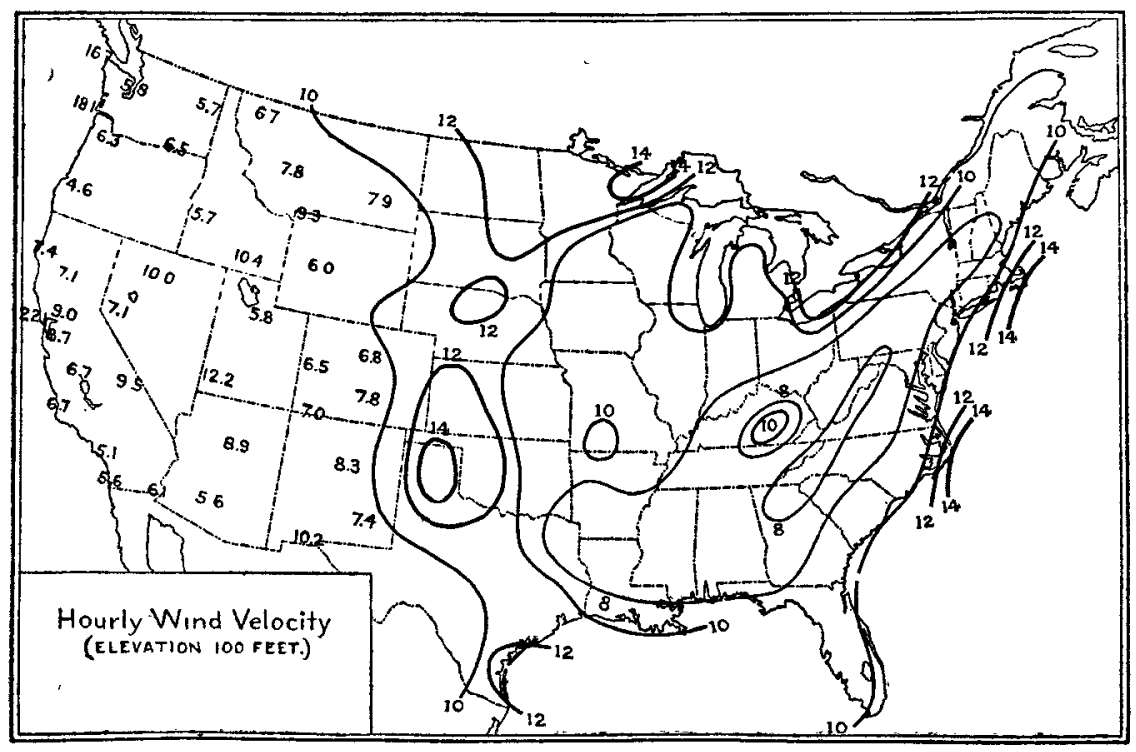

Figure 3

Over the interior, away from. large bodies of water; among the mountains; in forests; in sheltered valleys, lower wind velocities are the rule. Exposed mountain tops, like Mt. Washington, N. H. (about 6,300 feet), are much windier. The Mt. Washington records have shown velocities averaging over twenty-five miles an hour in summer, and over thirty miles in winter. Mt. Weather, Va. (1,700 feet), and Mt. Mitchell, N. C. (6,700 feet), have much less wind because they are farther away from the northern storm paths.

Very striking is the broad zone of the Great Plains (" Plains Province"), with wind velocities closely resembling those along the eastern seaboard and the Great Lakes-winds which are ocean-like in character, as vast stretches of the Plains are themselves ocean-like in their monotony and in their unbroken sweep to the far-away horizon. No more striking illustration of the wind velocities on the Great Plains have ever been given than Captain Lewis's description of the occasion, on the famous Lewis and Clark Expedition, when one of his boats, 
which was being transported on wheels, was blown along by the wind, the boat's sails being set! Surely this story emphasizes the analogy between the winds of the ocean and the winds of the Plains. Over this great treeless open country, but little retarded by friction, blow winds of remarkable uniformity and of relatively high velocity, averaging ten to twelve miles an hour, and even reaching fourteen or fifteen miles in the region of the Texas "Panhandle." Pike's Peak (14,134 feet), although more than twice as high as Mt. Washington, has much less wind than the New Hampshire summit because it is in a region of much less marked cyclonic control. The average velocities are 22 miles an hour for the year; 27.1 in March; 13.5 in July.

It is a climatic fact of great economic importance that the wind velocities over the Great Plains are so extraordinarily well adapted for driving wind-mills. The configuration of the continent, and the distance from primary sources of moisture supply, result in giving this great interior region a somewhat deficient rainfall. It is a district over most of which general farming without irrigation is a hazardous undertaking. To secure water for irrigating, for stock, and for domestic use, recourse must be had chiefty to underground supplies. This necessitates pumping, and in the wind conditions of these very same Plains-in the relatively high and steady wind velocity-we have a source of power which is economical and reliable. Hence the windmill is one of the most characteristic features of the Great Plains. Far away in the distance, long before the farm buildings themselves can be seen, the tall steel frame, with its revolving wheel at the top, stands out against the distant sky line. We have here a curious and interesting climatic compensation, of inestimable money value to the farmers of our western Plains. In other parts of our country, also, where there is no constant necessity of irrigation, and where the winds, although less favorable as a source of power, are nevertheless reasonably well adapted for driving windmills much of the time, there should be an increasing use of this cheap and effective source of power for pumping water to be used temporarily in times of drought.

As illustrations of the work done by windmills, the following cases, reported by Dr. Frank Waldo, may be cited ${ }^{18)}$. A wheel 12 feet in diameter raised 50,000-100,000 gallons of water a month to a height of 50 feet (Texas). A 10 -foot wheel in Wisconsin raised 50 barrels of water daily to a height of 50 feet. A 10-foot wheel in Iowa raised enough water, to a height of 40 feet, to supply 300 head of cattle. In Missouri, a 16-foot wheel ground 20 bushels of corn in an hour. In Nebraska, a 10-foot wheel raised 1,000 gallons of water daily to a height of 70 feet.

So widely varying, under the influence of local topography, are the wind velocities over our western mountain and plateau region 
("Plateau Province"), and so few and scattering are the available data, that lines of equal wind velocities cannot well be drawn for that section. The chart (Fig. 3) shows velocities varying from 5-6 to 10-12 miles an hour. It is to be expected that, in such a broken and mountainous topography, the velocities will, on the whole, be distinctly smaller than those on the Great Plains. The most sheltered localities are generally the least windy. Yet the use of windmills is by no means impossible in many parts of the Plateau Province, and the judicious choice of windmill sites where the conditions are most favorable would provide many localities with the means of irrigating.

In spite of its name, our Pacific coast ("Pacific Province"), at its northern exposed stations ("Northern Pacific"), has higher average wind velocities (16-22 miles an hour) than those at exposed points on the Atlantic coast. The conditions on these two coasts are, however, different, and cannot be directly compared. The higher velocities along the Pacific seaboard have been recorded on bluffs several hundred feet in elevation. South of San Francisco, light winds prevail ("Southern Pacific Province"), for storm control becomes less and less marked as we go southward along the coast.

Maximum Wind Velocities. - - The most violent winds with which man has to contend in the United States are those of the tornado. The velocities-unrecorded because too great for any instrument to register-run up to 150,200 , possibly even to 300 miles an hour. Considering the size of the country, tornado blasts are relatively rare. They are in general limited to the "tornado belt" of the eastern United States, i. e., to.the central and southern Mississippi Valley region, and from there, with decreasing frequency, to the States lying to the west and east. The sudden squall winds which accompany severe thunderstorms are responsible, next after tornadoes, for the highest winds of our interior districts. In many of our forests, often far from the beaten track of man's present-day wanderings, records of former tornadoes, and of other high winds, are preserved, decades after the occurrence of the blasts which uprooted and broke off the trees. "Fossil" tornadoes may be distinguished by the tangle and criss-crossing of the trees, which give the evidence of the tornado whirl. A straight "slash" through the forest, with the trees all prostrate in the same direction, is the "fossil" record of a straightline gale or of a thundersquall.

West Indian hurricanes are responsible for the maximum wind velocities which are recorded along the south Atlantic and Gulf coasts, while severe winter storms bring the highest winds at the stations along the margin of the north Atlantic, north Pacific and Great Lakes.

For engineers and for architects it is important to know the absolute maximum of wind velocity which may occur in any district. But 
for ordinary purposes, and as a matter of popular interest, a much more general indication of our highest wind velocities amply suffices. Excluding the relatively rare tornado, winds blowing for short periods at the rate of 50-75 miles an hour may bccasionally be expected at interior stations, while velocities of 75 to 80 or 90 miles are not unlikely to occur in the most severe gales along our coasts. Our winter gales, and our summer and autumn hurricane winds along the Atlantic seaboard, too often bring danger and disaster to our shipping. The storm warnings of the Weather Bureau, indicating gales dangerous to navigation, are seen by our mariners with discouraging frequency.

In our western mountain regions the highest winds accompany the more severe winter storms, and have an important economic bearing in that they drift and pack the snow in the mountains, consolidating it for subsequent slow melting in spring and summer, and thus providing a more uniform and a more continuous supply of water for irrigation. Taking the country as a whole, the lowest wind velocities are found in the southwestern interior.

Exposed stations on the Pacific coast from San Francisco northward ("Northern Pacific Province") are subject, during the passage of severe winter storms, to gales with velocities running up to from 50 to 90, or even more, miles an hour. To the south ("Southern Pacific Province"), the maximum velocities are much lower, the highest winds blowing when winter storms move southward along the coast, or in connection with low-pressure areas over the interior (Sonora type). Point Reyes, Cal., a very exposed station, a little north of the Golden Gate, has recorded five-minute velocities of 110 miles an hour, and extreme velocities, in shorter periods, of 120 miles of hour ${ }^{19)}$. The wind directions in these Pacific coast gales are southeasterly or northwesterly. Shipping is liable to suffer damage, but inland the loss, if any, is chiefly confined to the uprooting of standing timber. Occasionally, even in central and southern California, strong winds may damage standing crops.

Seasonal and Diurnal Variation in Wrnd Velocity.-With the annual progress of the seasons there comes a seasonal variation in our wind velocities. For the country as a whole, spring (March, April) is, in general, the windiest time of the year; middle and late summer (July, August), the calmest. March is proverbially a windy month. In the long run it deserves its reputation ${ }^{20)}$. It is a transition month. The combined influence of the still active winter storm control and the rapidly-increasing diurnal (solar) control of summer makes for active wind movement. The difference between the average wind movement in the windiest and calmest months varies between $30 \%$ and $70 \%$ in different sections. The least difference is found over the Plains, the upper Lakes and the South Atlantic coast; the greatest, on 
the north Pacific coast. It is a fact of notable economic importance that there is comparatively little seasonal difference in the wind velocities over the Great Plains. It is also economically important that the highest winds which sweep over the Plains are most common in winter and spring, when the contrasts in temperature are most marked, and not in summer. The damage to crops from this source is thus minimized.

The general increase in wind velocity from a minimum in the early morning to a maximum at 2 or $3 \mathrm{p}$. $\mathrm{m}$. is a characteristic feature over most of the country, although there are exceptions, as on the Pacific coast. The change is most marked at inland stations, on clear days, and in summer, when storm control is least marked. Mr. P. C. Day has recently charted the average hourly wind velocities for the daylight hours ( $6 \mathrm{a} . \mathrm{m}$. to $6 \mathrm{p}$. m.) ; for the approximate hour of maximum wind morement ( $3 \mathrm{p}$. m.), and for the approximate hour of least wind movement $(6 \text { a. m. })^{21)}$. The daytime increase in wind velocity near the earth's surface over that of nighttime averages $20 \%-40 \%$, and may reach $50 \%$ or more. The average daylight velocities approximate 10 miles or more an hour over much of the country. The Great Plains are conspicuous on account of their high velocities (over 12 ; over 16 in the Texas Panhandle), which are about the same as those at exposed points along the Atlantic coast and on the Great Lakes. Comparing the extreme day and night velocities (i. e., the average velocities at 6 a. m. and 3 p. m.), we find that the increase in the afternoon velocity over that of early morning is most marked in regions of light winds, as in protected valleys of the Rocky and Appalachian Mountains (75-100\%). Over the Great Plains this increase is less $(30-50 \%)$. The Plains, then, stand out conspicuously in their wind conditions. They have relatively high average wind velocities; there is little seasonal variation in relocits; and the winds of nighttime are relatively higher, as compared with those of dartime, than is the case over much of the countrs. All this makes the winds of the Great Plains an important and reliable source of power.

\section{BibLIOGRAPHY.}

\section{A. Publications directly referred to in Text.}

$\therefore$ William Ferrel: "A Popular Treatise on the Winds," 8 vo., New York, 1890, p. 187.

2. Th. Hesselberg and H. L. Sverdrup: "Ueber den Einfluss der Gebirge auf die Luftbewegung längs der Erdoberfläche und auf die Druckverteilung." Veröff. Geophys. Inst. d. Cniv. Leipzig. 2te Serie. Heft 4. Leipzig, 1914, pp. 102-116. 2 pls.

3. A. G. MeAdie: "The Paradox of the East Wind." Pop. Sci. Mo., Vol. LXXXV, Sept., 1914, pp. 292-295.

4. Lorin Blodget: "Climatology of the United States," etc., 4to., Philadelphia, 1857, Chap. XI. 
E. F. B. White: "Topographic Influences on the Winds of our Weather Maps." Amer. Met. Journ., Vol. XII, May, 1895, pp. 15-19.

5. W. M. Davis : “Elementary Meteorology," 8 vo., Boston, 1894, Figs. 29 and 30, p. 98. (These figures, showing the annual frequency of wind directions at Kinderhook, in the Hudson Valley, trending north and south, and at Utica, in the Mohawk Valley, trending east and west, illustrate very strikingly the topographic control exerted by these two valleys on the direction of the prevailing winds.)

6. Alexander Buchan: "Report on Atmospheric Circulation." Vol. II, Physics and Chemistry, Pt. V. Report on the Scientific Results of the Voyage of $\boldsymbol{B}$. $\boldsymbol{M}$. s. "Challenger." 4to. London \& Edinburgh, 1889. The monthly and annual pressure charts are reproduced in Bartholomew's Atlas of Meterology, 1899, PIs. $11 \&$ 12, Text, pp. 13-14. See also: F. H. Bigelow: "Report on the Barometry of the United States, Canada and the West Indies." Report Chief of Weather Bureau for 1900-1901. Pt. II. Washington, D. C., 1902 (Monthly and annual isobaric charts, following p. 638).

7. Alfred J. Henry: "The Winds of the Lake Region," Mo. Wea. Rev., Vol. XXXV, Nov., 1907, pp. 516-520.

8. J. von Hann: "Handbuch der Klimatologie." 3d ed., Stuttgart, 1908, Vol. II, p. 396.

9. Ibid., Vol. I, p. 166.

10. See note 7 .

11. Report of the Chief of the Weather Bureau for 1896-97, Washington, D. C., 1897, p. 278.

12. See note 4, Chap. VIII.

13. See note 4, Chap. XI.

14. J. H. Coffin: "Winds of the Globe." Smithson. Contr. to Knowl, Vol. 20, fol. Washington, 1875.

15. See note 1, p. 218.

16. Mark W. Harrington: "The Texan Monsoons." Bull. Phil. Soc. Wash., Vol. VII, Feb., 1894, pp. 293-308; Amer. Met. Journ., Vol. XI, 1895-96, pp. 41-54.

17. P. C. Day: "The Winds of the United States and their Economic Uses." Yearbook U. S. Dept. of Agric. for 1911, 8 vo., Washington, D. C., 1912, pp. 337-350, PI. XXIII.

18. Frank Waldo: "Wind as a Motive Power in the United States." Rev. of Rev. (New York), Vol. XII, Sept., 1895, pp. 299-302.

19. A. G. MeAdie and W. W. Thomas: "Some High Wind Records on the Pacific Coast." Mo. Wea. Rev., Vol. XXXI, Feb., 1903, pp. 64-68.

20. William R. Stockman: "March and Winter Winds," ibid, May, 1903, pp. 223225.

21. See note 17 .

B. General: Publications not referred to in Text, and Bibliographies.

Bibliography of Meteorology. A Classified Catalogue of the Printed Literature of Meteorology from the Origin of Printing to the Close of 1881; with a Supplement to the close of 1889, and an Author Index. Prepared under the Direction of Brig. Gen. A. W. Greely, Chief Signal Officer, U. S. Army, Edited by Oliver L. Fassig. 4to. Washington, D. C., 1891. Part III-Winds. (Geographical Distribution of Winds: United States, pp. 126-128.)

International Catalogue of Scientific Literature. F. Meteorology, 8 vo., London. First issue in 1902, contains references to the literature of 1901. Last volume issued concerns the literature of 1912.

"Charts showing Average Velocity and Direction of the Wind, prepared from observations for Seventeen Years." U. S. Signal Service, Washington, D. C., 1891. 
36 charts fol. (These charts show (1) the average velocity of the wind at 65 representative stations at the hours ending at $8 \mathrm{~A}$. M. and $8 \mathrm{P}$. M., 75th meridian time respectively; (2) the prevailing direction of the wind at a number of stations east of the Rocky Mts.; (3) the highest and lowest average hourly velocity of the wind, with the hour of occurrence; (4) the average number of times a velocity of 25 miles, or more, has been observed at the principal Lake stations.)

Report of the Chief of the Weather Bureau for 1896-97. 4to. Washington, D. C., 1897, pp. 277-278, Charts I and III, show prevailing winds for January and July, based on 19 years of observations ("Climatic Statistics," by A. J. Henry).

F. H. Bigelow: "The Average Monthly Vectors of the General Circulation in the United States." Mo. Wea. Rev., Vol. XXXII, June, 1904, pp. 260-263.

T. H. Davis: "Annual Wind Resultants," ibid., Vol. XXX, Nov., 1902, pp. 519-532. "Direction of Local Winds as Affected by Contiguous Areas of Land and Water," ibid., Vol. XXXIV, Sept., 1906, pp. 410-413.

H. H. C. Dunwoody: "Summary of International Meteorological Observations," Bulletin A., U. S. Weather Bureau, fol. Washington, D. C., 1893. Text and 59 charts (including monthly charts of temperature, pressure and prevailing winds). A. J. Henry: "Climatology of the United States." Bulletin Q, U. S. Weather Bureau, 4to. Washington, D. C., pp. 67-75 on Winds.

A. G. McAdie: "The Winds of Boston and Vicinity." Annals Astron. Obsy. Harv. Coll., Vol. 73, Pt. 3, Cambridge, 1916.

F. Waldo: "Daily March of the Wind Velocities in the United States." Amer. Journ. Sci., 3d Ser., Vol. XLIX, June, 1895, pp. 431-442.

"The Geographical Distribution of the Maximum and Minimum Hourly Wind Velocities, and their Relations to the Average Daily Wind Velocities for January and July, for the United States." Amer. Met. Journ., Vol. XII, July, 1895, pp. 75-89.

"Synehronous or Simultaneous Geographical Distribution of Hourly Wind Velocities in the United States," ibid., Sept., 1895, pp. 145-151.

"The Relations of the Diurnal Rise and Fall of the Wind in the United States." Amer. Journ. Sci., 3d Ser., Vol. L, Sept., 1895, pp. 235-238. 